\title{
Artificial Cell Therapy: New Strategies for the Therapeutic Delivery of Live Bacteria
}

\author{
Satya Prakash* and Mitchell Lawrence Jones \\ Biomedical Technology and Cell Therapy Research Laboratory, Department of Biomedical Engineering \\ and Artificial Cells and Organs Research Centre, Faculty of Medicine, McGill University, \\ 3775 University Street, Montreal, Québec, Canada H3A 2B4
}

Received 20 January 2004; revised 19 July 2004; accepted 27 July 2004

\begin{abstract}
There has been rapid growth in research regarding the use of live bacterial cells for therapeutic purposes. The recognition that these cells can be genetically engineered to synthesize products that have therapeutic potential has generated considerable interest and excitement among clinicians and health professionals. It is expected that a wide range of disease modifying substrates such as enzymes, hormones, antibodies, vaccines, and other genetic products will be used successfully and will impact upon health care substantially. However, a major limitation in the use of these bacterial cells is the complexity of delivering them to the correct target tissues. Oral delivery of live cells, lyophilized cells, and immobilized cells has been attempted but with limited success. Primarily, this is because bacterial cells are incapable of surviving passage through the gastrointestinal tract. In many occasions, when given orally, these cells have been found to provoke immunogenic responses that are undesirable. Recent studies show that these problems can be overcome by delivering live bacterial cells, such as genetically engineered cells, using artificial cell microcapsules. This review summarizes recent advances in the therapeutic use of live bacterial cells for therapy, discusses the principles of using artificial cells for the oral delivery of bacterial cells, outlines methods for preparing suitable artificial cells for this purpose, addresses potentials and limitations for their application in therapy, and provides insight for the future direction of this emergent and highly prospective technology.
\end{abstract}

\section{ORAL DELIVERY OF LIVE BACTERIAL CELLS FOR THERAPY: POTENTIALS AND LIMITATIONS}

Intestinal flora are key to human health, as they play an important role in metabolic processes $[1,2]$. With advances in genetic engineering, it is now possible to enhance this metabolic capacity. It is also possible to engineer nonpathogenic normal cells for desired metabolic activity and to produce therapeutic agents. Thus, inherited or engineered availability of special properties in these cells make them excellent candidates for therapeutic use. Indeed, the concept of ingesting live microorganisms for therapy (probiotics) can be traced back to the beginning of the 20th century [3].

Since then, several promising studies have substantiated this concept. For example, oral feeding on Lactobacillus bacteria has been used for prevention and treatment of diarrhea in children $[4,5,6]$. Similarly, feeding on Lactobacillus casei strain Shirota (LcS) has been shown to enhance innate immunity [7]. Bacteria such as Bifidobacteria have been successfully used to treat intestinal disorders and to prevent rotaviral diarrhea in children [8]. In premature infants, feeding on lyophilized strains of $B$ breve or $B$ longum can restore the imbalance in the gut microflora $[9,10]$. These latter strains can also suppress azomethane-induced colon carcinogenesis in rats [9]. Cultures of $B$ longum reduced carcinogenesis by a food mutagen, 2-amino-3-methylimidazo [4,5f] quinoline [9]. Certain strains of Lactobacilli have also been shown to significantly suppress intestinal tumors induced by chemical mutagens $[9,11]$. Some human feeding studies with Lactobacilli suggest a possible effect in lowering cholesterol $[9,12,13]$. Recently, in a randomized, double-blind study, 27 healthy newborn infants were colonized with the nonpathogenic E coli 1917 during the first 5 days of life by daily oral inoculation $(1.0 \mathrm{~mL}$ suspension containing $10^{8}$ live cells). The colonization with true and potential bacterial pathogens was significantly reduced in infants receiving E coli 1917 [14]. Oral feeding on freezedried live Lactobacillus (LB) acidophilus cells in subjects with advanced chronic kidney failure has been shown to lower elevated levels of uremic toxins [15].

In another study, a carcinogen, nitrosodimethylamine (NDMA), and the toxin dimethylamine (DMA) were lowered significantly by oral feeding on LB cells with no side effects of the therapy. Other studies indicate that renal failure stones can be treated using high concentrations of freeze-dried lactic acid bacteria [16], LB cells can change small bowel pathobiology reducing in vivo generation of toxins and carcinogens with no adverse side effects [15], plasma uremic toxins can be markedly lowered in patients after oral administration of LB cells [16], and bactericides 
and $E$ coli cells can be used to treat gastrointestinal (GI) tract disorders [17]. In addition, there is also evidence to suggest that ingesting a strain of Bifidobacterium lactis can enhance general immunity [18], and that ingesting certain strains of LB cells can increase secretary IgA levels and rotavirus-specific antibodies $[19,20]$. Recently, it was demonstrated that Lactococcus lactis bacteria can be genetically engineered to produce cytokine interleukin-10 (IL-10) and it can be used for inflammatory bowel disease (IBD) therapy by oral delivery [21]. Thus, there is considerable evidence supporting the importance of oral feeding on live normal or genetically engineered bacterial cells for diverse therapeutic applications highlighting the underlying potential of this approach to therapy. Table 1 summarizes the potential of the use of bacterial cells to therapy.

While existing live bacterial cell therapies show great therapeutic potential, they have several limitations. For instance, when given orally bacterial cells are exposed to difficult GI conditions and experience low survival $[22,23,24]$ requiring that a large dosage be given. However, large quantities of live bacterial cells, delivered orally, can stimulate host immune response [25, 26, 27, 28, 29]. In fact, a normal daily intake of $250 \mathrm{~mL}$ of yogurt would only correspond to 500 milligrams of cell dry weight (CDW) of bacteria, and of those bacteria ingested only $1 \%$ would survive gastric transit limiting the overall therapeutic effect [30]. Furthermore, when given orally, live bacterial cells can be retained in the intestine $[26,27,31,32]$ and repeated large doses could result in their replacing the normal intestinal flora [33]. In addition, risk of systemic infections, deleterious metabolic activities, adjuvant side effects, immunomodulation, and risk of gene transfer limit their widespread use $[26,32,34,35,36]$. These limitations have raised concerns about the safety of the approach and prevented receiving approval from regulatory agencies and hence precluded the adoption of this form of therapy in regular clinical practice $[26,32,34,35,36,37]$.

\section{POTENTIAL OF ARTIFICIAL CELLS FOR ORAL DELIVERY OF LIVE BACTERIAL CELLS FOR THERAPY}

\section{Principle of artificial cells for oral delivery of bacterial cells for therapy}

Artificial cell microencapsulation is a technique used to encapsulate biologically active materials in specialized ultrathin semipermeable polymer membranes [58, 59]. The polymer membrane can protect encapsulated materials from harsh external environments while at the same time allowing for the metabolism of selected solutes capable of passing into and out of the microcapsule. In this manner, the enclosed material (in this case live bacteria) can be retained inside and separated from the external environment, making microencapsulation particularly useful for biomedical and clinical applications [60, 61, 62]. Studies show that artificial cell microcapsules can be used for oral administration of live genetically engineered cells that can be useful for therapeutic functions $[63,64]$. Al-

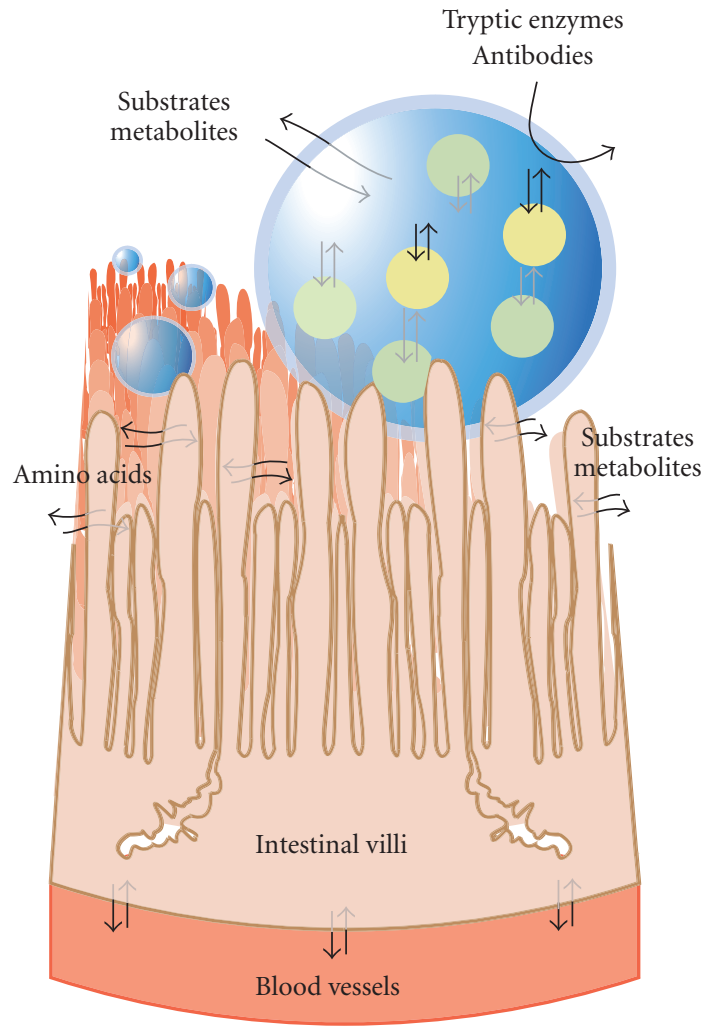

Figure 1. The principle of orally administered artificial cells containing bacterial cells for therapy. The semipermeable membrane excludes antibodies, tryptic enzymes, and other external materials but allows smaller molecules (amino acids, bile acids, ammonia, gasses, etc) to enter and be acted on by the enclosed microorganisms. Also, small molecules (including some peptides) produced by the enclosed bacterial cells can be designed to diffuse out into the body for therapy.

though the live cells remain immobilized inside the microcapsules, microencapsulation does not appear to hinder their growth kinetics [65]. The microcapsules remain intact during their passage through the intestinal tract and are excreted intact in the stool in about 24 hours. The cells are retained inside, and excreted with, the intact microcapsules addressing many of the major safety concerns associated with the use of live bacterial cells for various clinical applications. The membranes of the microcapsules are permeable to smaller molecules, and thus the cells inside the microcapsules metabolize small molecules found within the gut during passage through the intestine $[58,63,64,65,66,67]$. Figure 1 summarizes the basic concept of artificial cells for oral delivery of bacterial cells for therapy.

The GI tract provides a blood/environment interface that we use often for nutrition, excretion, maintaining water and electrolyte balance, and occasionally for various therapies including the delivery of drugs. Interaction with this system through input of nutrients, water, and drugs 
TABle 1. Potential therapies based on the oral delivery of free live bacterial cells.

\begin{tabular}{|c|c|c|c|}
\hline Disease/therapy & Culture & Mode of action & References \\
\hline Diarrhea & $\begin{array}{l}\text { L rhamnosus } \\
\text { L casei } \\
\text { L reuteri } \\
\text { L GG B lactis } \\
\text { B bifidum } \\
\text { B Bb12 }\end{array}$ & $\begin{array}{l}\text { Reduction of antibiotic-associated diarrhea in children and adults, } \\
\text { treatment and prevention of rotavirus and acute diarrhea in children and } \\
\text { adults, prevention of traveler's diarrhea. Certain strains of lactic acid } \\
\text { bacteria promote serum and intestinal immune responses to rotavirus and } \\
\text { thus may be important in establishing immunity against rotavirus } \\
\text { infections. }\end{array}$ & $\begin{array}{l}{[4,5,6,8,} \\
17,19,20, \\
38,39,40, \\
41,42,43, \\
44,45,46] \\
\text { US } \\
\text { Patent } \\
5443826\end{array}$ \\
\hline $\begin{array}{l}\text { Colorectal } \\
\text { cancer }\end{array}$ & $\begin{array}{l}\text { Lactobacillus } \\
\text { B breve } \\
\text { B longum }\end{array}$ & $\begin{array}{l}\text { Mechanisms may include enhancing the host's immune response; } \\
\text { binding and degrading potential carcinogens; alterations in the intestinal } \\
\text { microflora incriminated in producing recognized carcinogens (eg, bile } \\
\text { acid-degrading bacteria); producing anticarcinogenic or antimutagenic } \\
\text { compounds in the colon; alteration of the metabolic activities of the } \\
\text { resident microflora; alteration of physicochemical conditions; effects on } \\
\text { general physiology. }\end{array}$ & $\begin{array}{l}{[9,10} \\
11,47]\end{array}$ \\
\hline $\begin{array}{l}\text { Inflammatory } \\
\text { bowel disease }\end{array}$ & $\begin{array}{l}L \text { lactis } \\
L G G\end{array}$ & $\begin{array}{l}\text { Could provide an adjunct nutritional therapy for Crohn's disease, as the } \\
\text { bacteria increase gut IgA immune response promoting the gut } \\
\text { immunological barrier. }\end{array}$ & $\begin{array}{l}{[17,48]} \\
\text { US } \\
\text { Patent } \\
5443826\end{array}$ \\
\hline Ulceration & $L$ acidophilus & $\begin{array}{l}\text { Downregulation of } H \text { pylori infection by inhibition of intestinal cell } \\
\text { adhesion and invasion. }\end{array}$ & [49] \\
\hline $\begin{array}{l}\text { Steatorrhea of } \\
\text { lipids } \\
\text { (malabsorption } \\
\text { of lipids) }\end{array}$ & B plantarii & $\begin{array}{l}\text { Bacteria express lipolytic activity with substantial enzyme stability in } \\
\text { human gastric juice leading to the increased absorption of lipids in the } \\
\text { small intestine. }\end{array}$ & {$[50,51]$} \\
\hline $\begin{array}{l}\text { Enhanced } \\
\text { immunity }\end{array}$ & $\begin{array}{l}\text { L acidophilus } \\
\text { L casei (LcS) } \\
\text { L GG } \\
\text { B lactis } \\
\text { B bifidum }\end{array}$ & $\begin{array}{l}\text { By one mechanism, innate immunity is enhanced by stimulating the } \\
\text { activity of splenic NK cells. While antigen-feeding alone was shown to } \\
\text { prime for an immune response, cofeeding on antigen and probiotic } \\
\text { bacteria suppressed both antibody and cellular immune responses and } \\
\text { may have the potential to attenuate autoimmune diseases (eg, } \\
\text { encephalomyelitis) by jointly dosing with myelin basic protein and } \\
\text { probiotic bacteria. }\end{array}$ & $\begin{array}{l}{[7,52} \\
53,54]\end{array}$ \\
\hline
\end{tabular}

(1) Bacteria may bind or incorporate cholesterol directly into the cell membrane. $\begin{array}{lll}\text { Lower } & \text { L acidophilus } & \text { (2) Bile salt hydrolase (BSH) enzyme deconjugates intraluminal bile acids } \\ \text { cholesterol } & \text { L bulgaricus } & \text { making them less likely to be reabsorbed into the enterohepatic }\end{array}$

cholesterol L bulgaricus circulation $(\mathrm{ECH})$, causing de novo synthesis of bile acids from blood serum cholesterol (Figure 2).

Small bowel bacterial overgrowth is well known to occur in end-stage kidney failure and is responsible for producing uremic toxins and

Chronic kidney L acidophilus contributing to decreased nutritional well-being. Certain bacteria are failure Lactic acid shown to reduce blood levels of uremic toxins produced in the intestine as bacterial putrefactive metabolites, especially that of indican, bacteria dimethylamine, and nitrosodimethylamine (a carcinogen) by inhibiting bacterial production by means of correcting the intestinal microflora.

$L$ acidophilus, L plantarum

Kidney stones L L brevis $S$ thermophilus $B$ infantis O faecalis
Urinary excretion of oxalate, a major risk factor for renal stone formation and growth in patients with idiopathic calcium-oxalate urolithiasis, can be greatly reduced with treatment using a high concentration of freezedried lactic acid bacteria. Oxalate-degrading enzymes produced by these microorganisms or by Oxalobacter-type bacteria breaks down the unwanted oxalate and can be used to prevent the subsequent evolution of kidney stones. 


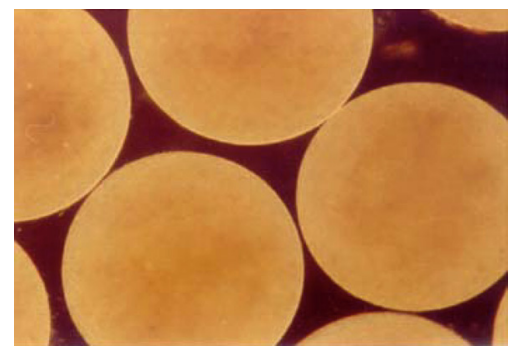

(a)

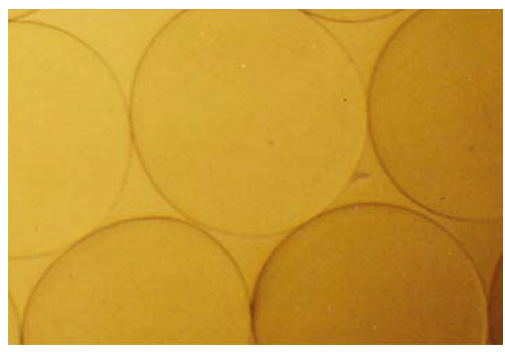

(c)

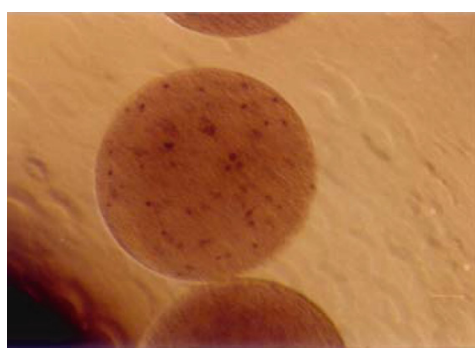

(b)

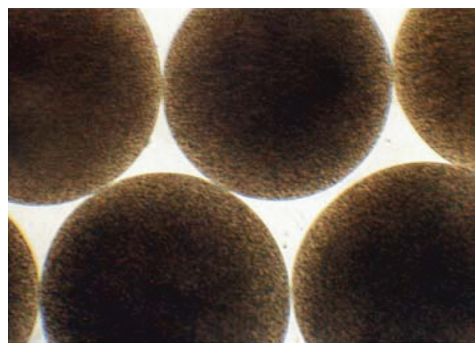

(d)

FIGURE 2. Artificial cells for bacterial cell therapy in kidney failure, elevated blood cholesterol, and other diseases. (a) Empty APA artificial cells. (b) APA membrane artificial cells with visible engineered E coli DH5 cells; with permission from Chang and Prakash [72]. (c) Empty APA artificial cells. (d) APA membrane artificial cells with thousands of engineered L plantarum 80 (pCBH1) cells; with permission from Jones et al [101].

is further complicated by the fact that the GI tract maintains several internal cycles used to preserve the balance of various molecules like bile acids, amino acids, and other recyclable molecules. This enterorecirculation thus provides an opportunity for the therapeutic action of encapsulated bacterial cells. By this motivation, interaction with this vast interface poses great interest to nutritional health scientists, advocates of probiotics, designers of oral drugs, and more recently those interested in oral therapy with live bacterial cells.

Artificial cells are enormously versatile in that they may contain gasses, drugs, enzymes, antibodies, cell extracts, polymers, proteins, and evenwhole cells. For many applications a single trapped enzyme or delivered drug may provide a curative effect; however, in many other cases the breakdown of an unwanted metabolite, or the production of a protein, may be better carried out by a microorganism. That is to say, the complex metabolism of various microorganisms can be encapsulated and used, in effect, as miniature bioreactors for therapy. Also, the hardy growth characteristics and short replication times of various bacterial strains make them perfect for mass production and as effective agents for orally delivered artificial cell therapy. Furthermore, as mentioned earlier in the last two decades, there has been an explosive increase in molecular biology research leading to the generation of many genetically engineered microorganisms with special properties. Microorganisms can be easily en- gineered to overproduce enzymes and peptides and to metabolize large amounts of unwanted metabolites and others. For these reasons, artificial cells containing bacterial cells are very good candidates for oral artificial cell therapy Figure 2. This concept has immediate application for microencapsulation-based oral therapy in renal failure and liver failure [63], physiologically responsive gene therapy $[58,68]$, and somatic gene therapy [69].

\section{Methods for preparing artificial cells}

The versatility of various formulations of artificial cells has been well documented; however, choosing a membrane is not a "one-size-fits-all" decision-artificial cell membranes should be selected or designed for each specific therapeutic device, as one may engineer several different membranes for artificial cell preparations with required membrane properties for a desired application. The use of different membranes allows for variations in permeability, mass transfer, mechanical stability, buffering capability, biocompatibility, and other characteristics. A balance, however, has to be maintained among the physical properties of capsule membranes so as to support the entrapped cells' survival. The mass transport properties of a membrane are critical since the influx rate of molecules, essential for cell survival, and the outflow rate of metabolic waste ultimately determine the viability of entrapped cells. Ordinarily the desired capsule 


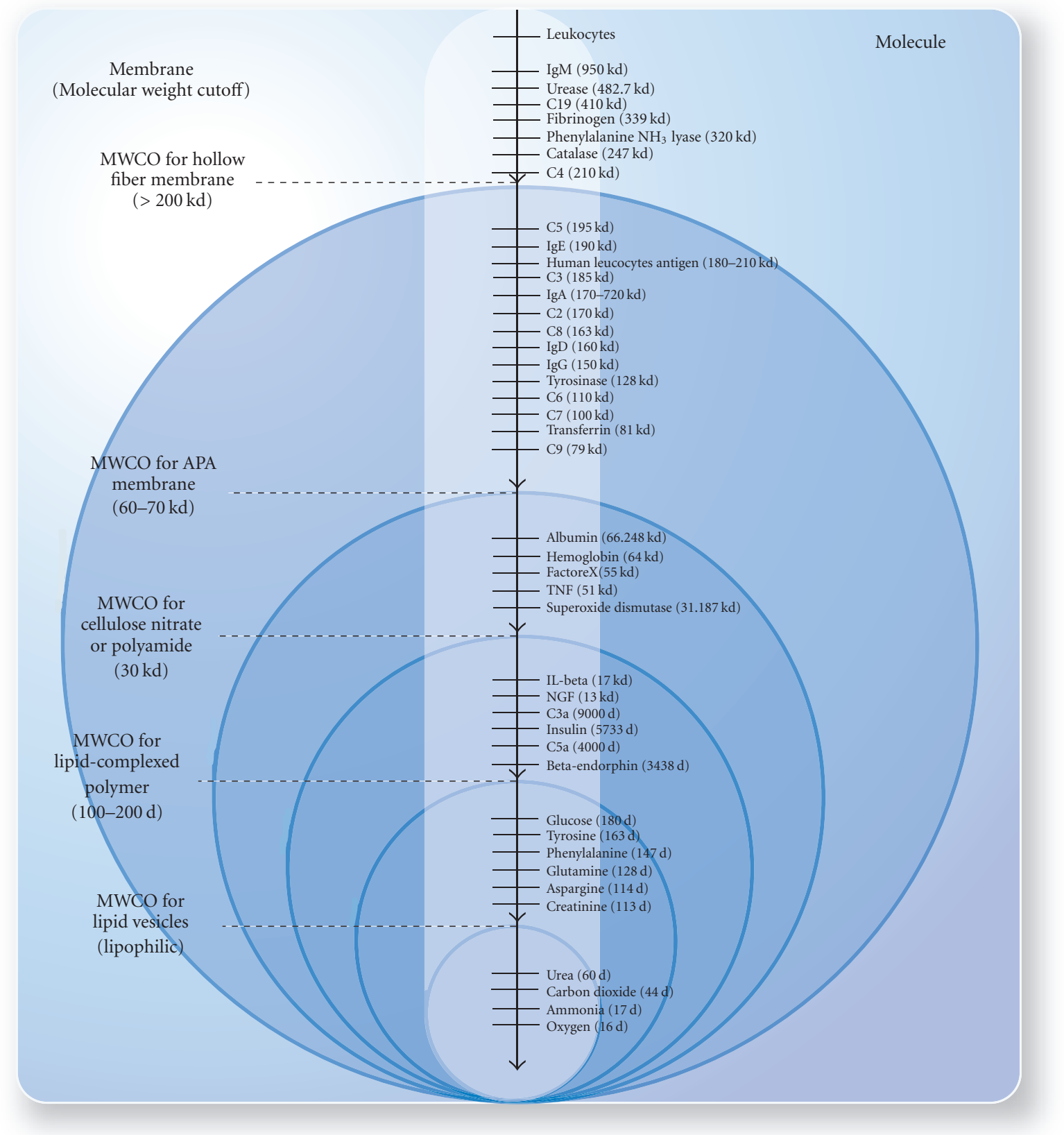

Figure 3. Molecular cutoff of different types of microcapsule membranes [72]. The molecular weights of various cells, enzymes, antibodies, complement components, proteins, peptides, and metabolites are listed on the right. Abbreviations: C2-9 and C19, various components of the complement cascade; Ig, immunoglobulin; IL-1, interleukin 1; NGF, nerve growth factor.

permeability is determined by the molecular weight cutoff (MWCO) and is application-dependent. The MWCO is the maximum molecular weight of a molecule that is allowed passage through the pores of the capsule membrane [70]. For transplantation, the MWCO must be high enough to allow passage of nutrients but low enough to reject antibodies and other immune molecules. The MWCO of orally delivered microcapsules must allow for the passage of unwanted metabolites from the plasma into the microcapsule and then must either facilitate the subsequent removal of the altered molecule or provide for its storage [70]. The most common type of membrane used for cell therapy is the single alginate-based polymer membrane; however, several other substances are being used such as various proteins, polyhemoglobin, and lipids [70, 71]. Yet another approach for membrane composition is to use a biodegradable synthetic polymer such as polylactide, polyglycolic acid, and polyanhydride. Figure 3 summarizes some commonly used artificial cell membranes and their molecular properties. The 
variability of artificial cell membranes allows for many possibilities in live cell therapy and other procedures and raises expectations for their widespread use in the future.

\section{The classic method of preparing artificial cell microcapsules containing live bacterial cells}

There are various methods available for preparing artificial cells containing live bacterial cells for therapy. For example, for preparation of the classic alginatepolylysine-alginate (APA) membrane, the live bacterial cells are suspended in a matrix of the natural polymer alginate $(1.5 \%)$. The viscous polymer-bacterial suspension is passed through a 23-gauge needle using a syringe pump. Sterile compressed air, passed through a 16-gauge coaxial needle, is then used to shear the droplets coming out of the tip of the 23-gauge needle. The droplets are allowed to gel for 15 minutes in a gently stirred ice-cold solution of solidifying chemicals, such as $\mathrm{CaCl}_{2}(1.4 \%)$. After gelation in the $\mathrm{CaCl}_{2}$, the beads are then washed with HEPES $(0.05 \%$ in HEPES, pH 7.20), coated with polylysine $(0.1 \%$ for 10 minutes $)$ and washed again in HEPES $(0.05 \%$ in HEPES, pH 7.20). The resultant capsules are then coated by reaction with alginate $(0.1 \%$ for 10 minutes) and washed with appropriate chemicals to dissolve their inner core content. For this step a 3.00\% citrate bath $(3.00 \%$ in $1: 1$ HEPES-buffer saline, $\mathrm{pH} 7.20)$ is often used. The microcapsules formed can then be stored at $4{ }^{\circ} \mathrm{C}$ in minimal solution ( $10 \%$ cell nutrient to $90 \%$ water).

\section{Mechanical stability}

If more sturdy microcapsules are required and the above method fails to produce the desired quality of microcapsules, a second more complex method can be employed. It is a 2-step method developed by Wong and Chang [73, 74]. Briefly, much smaller alginate beads containing live cells are produced at a much higher shear force than above. One millilitre of these small alginate gel beads are then added to $1 \mathrm{~mL}$ solution of sodium alginate $(1.2 \%-1.6 \%)$. The rest of the method is the same as above starting with droplet formation using a $23 \mathrm{G}$ needle. This extra step will prevent cell leakage and limit the exposure of surface antigens found on the membranes of the encapsulated microorganisms.

\section{Large-scale production of artificial cell microcapsules}

If large-scale preparation of sterile microcapsules containing bacterial cells is required, automated encapsulators such as the Inotech Encapsulator produced by Biosystems International Inc (Rockville, Md, USA) can be used. This type of encapsulator is not based on the shear drop method, but is based on the principle that a laminar liquid jet is broken into equally sized droplets by a superimposed vibration. Furthermore, an electrostatic charge may be applied to each microcapsule so that a funnel-like spray of droplets is produced and a more homogeneous set of microcapsules result. This type of microencapsulator can manufacture large numbers of superior-quality microcapsules and can facilitate the procedures described in the methods outlined above.

\section{Membranes used for artificial cells for oral delivery of bacterial cells}

The design of a membrane, intended for use in oral live bacterial cell therapy, must take into consideration several primary factors so as to minimize microbial death and maximize therapeutic effectiveness. To assure their efficacy, artificial cells intended for oral administration must be designed to protect their living cargo against both acidic environment of the stomach and immunoglobulin released by the intestinal immune response. For this reason research has historically focused on the buffering capability of microcapsule membranes in simulated human gastric environments and the ability of various membranes to oppose immunoglobulin penetration. Several examples of artificial cell design follow with emphasis on research related to these core and essential characteristics.

Rao et al[22] described a method to encapsulate freeze-dried $B$ pseudolongum using cellulose acetate phthalate (CAP) coated with beeswax, showing that encapsulated $B$ pseudolongum is able to survive the simulated gastric environment in larger numbers than nonencapsulated cells $[22,24]$. A Brazilian group recently prepared probiotic microorganisms including Lactobacillus and Bifidobacteria by spray drying, again using CAP as the wall material, evaluated the resistance of these microorganisms to drying at three temperatures, and evaluated in vitro tolerance to $\mathrm{pH}$ values and simulated human bile concentrations [75]. They found that the CAPprepared microorganisms were better able to protect the microorganisms from an acidic environment and were resistant to conditions of a simulated human bile environment [75]. In another study, encapsulation of Bifidobacteria inbutter-oil-and-whey-based medium was proposed but was shown to be ineffective in preventing acid injury to bacteria in both low acid and high acid environments [76].

Overall, calcium alginate and k-carrageenan-locust bean gum gel beads have been the two most commonly used polymers for immobilizing viable cells [77, 78]. Alginate beads, however, have displayed the undesirable property of limited acid resistance, and it has been reported that alginate beads undergo shrinkage and decreased mechanical strength in acidic conditions $[78,79]$. In order to overcome this challenge, coating the bacteria by cross-linking with a carboxyvinyl polymer carrier has been suggested and was shown to be effective for intestinal delivery [80]. K-carrageenan-locust bean gum gel beads are less sensitive to acidic conditions than alginate beads and hence have been used for lactic fermentation. The formation of k-carrageenan-locust bean gum beads, however, requires a high concentration of potassium ions 


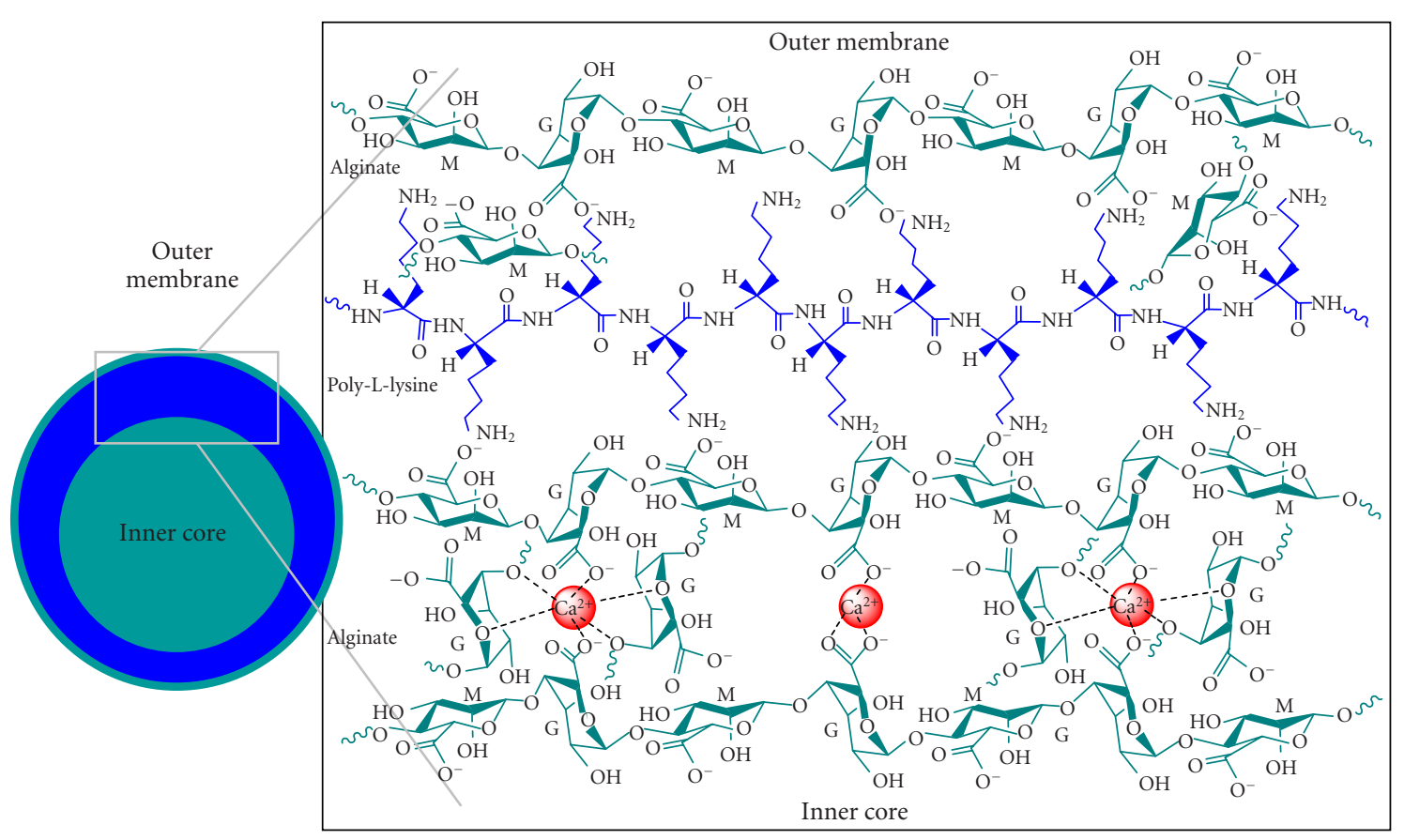

FIGURE 4. Electrostatic interactions of polymer layers in alginate-poly-L-lysine-alginate artificial cell membrane.

and for this reason two major limitations preclude their widespread use: firstly, high concentrations of potassium ions could potentially damage the cells of $B$ longum during lactic fermentation [81, 82]; and secondly, it has been pointed out that as potassium ions are important in maintaining electrolyte equilibrium, their inclusion in the diet in large amounts would not be recommended $[1,83]$. Gellan-xanthan beads, on the other hand, are not only acid-resistant but are also stabilized by calcium ions [84], suggesting that they could be a good candidate for immobilizing bacterial cells and protecting them against acid injury [85]; however, gellan-xanthan beads do not provide adequate immune protection.

Similarly, agarose microcapsules prepared by emulsification/internal gelatinization for oral delivery of Bacillus Calmette-Guerin (BCG) cells, although stable for up to 12 months in vitro, have not yet been shown suitable for oral delivery, as agarose membranes do not provide sufficient immunoprotection $[84,86]$. Thus, agarose microspheres with the addition of various polymer coatings have been proposed [87]. Among other formulations, gelatin and polymer-coated gelatin capsules have been studied for oral delivery of live bacterial cells $[88,89]$. Although gelatin (with $20 \% \mathrm{w} / \mathrm{v}$ of the polymer) has shown promising results in vitro, a radiological study among human volunteers has shown that uncoated gelatin capsules disintegrate within 15 minutes of ingestion [90,91].

Although a host of other formulations have been studied to date (including using gum arabic, milk-derived whey proteins, soluble starch, and others $[26,89,92,93$, $94,95,96,97])$ the most promising formulation is the en- capsulation of calcium alginate beads with poly-L-lysine (PLL) forming APA microcapsules. In the APA membrane microcapsule, alginate forms the core and matrix for the cell and PLL binds to the alginate core. Binding of PLL to alginate is the result of numerous long-chain alkylamino groups within PLL that extend from the polyamide backbone in a number of directions and interact with various alginate molecules, through electrostatic interactions. The resulting cross-linkage produces a stable complex membrane that reduces the porosity of the alginate membrane and forms permanent immunoprotective barriers as shown in Figure 4.

One possible drawback to this system is as some studies have suggested that APA microcapsules may provoke an inflammatory response [105], and although the latter was observed in cell transplantation studies, one can envision the possibility of similar adverse reactions during oral therapy especially when large quantities of microcapsules are used and further accentuated when the patient suffers from internal GI bleeding. The conventional APA microcapsule has thus been shown to pose limitations for general use in the oral administration of microencapsulated bacterial cells for therapy. Some studies have shown that this classic formulation has inadequate stability in the GI tract for some applications [106], while other researchers have shown that APA microcapsules have a controversial permeability [107]. Furthermore, it has been reported that it is difficult to obtain a membrane, optimizing all the properties requested for a successful clinical application, by the process of binary polyelectrolyte complexation [108]. 
A potential solution to these problems is the use of multilayer membrane formation based on the electrostatic attraction of oppositely charged macromolecules with a charge reversal at each step of the macroion adsorption. This technique makes it possible to modulate the MWCO and retain high mechanical stability at the same time. Specifically, Alginate/Poly-L-lysine/Pectin/ Poly-L-lysine/Alginate (APPPA), Alginate/Poly-L-lysine/ Pectin/Poly-L-lysine/Pectin (APPPP), and Alginate/PolyL-lysine/Chitosan/Poly-L-lysine/Alginate (APCPA) membranes have been prepared and tested for their strength and GI stability $[109,110]$. It has been shown that these multilayer membrane formulations perform well in GI stability tests, providing for increased resistance to complete dissolution in water, dilute acids, and base, as well as in the presence of ion cheaters, while allowing for more precise control over membrane permeability.

\section{Production and storage of artificial cells for oral delivery of bacterial cells}

The considerations for production and storage of artificial cells for oral delivery of bacterial cells have been outlined [111] and should include an evaluation of the stresses to which probiotic products are exposed during production and during passage in the GI tract. Certain stresses, associated with microcapsule production, have been identified that must be considered, including exposure to high concentrations of fermentation by products, harvesting procedures, freezing, drying, exposure to oxygen, and osmotic pressure from salts [111]. In the GI tract designers must minimize the stresses of long exposure times to stomach acid, antimicrobial compounds, bile acids, and oxygen, and the stress of rehydration in a highly acidic environment [111]. Siuta-Cruce and Goulet have shown that microencapsulation is an efficient barrier against chemical entities such as moisture, oxygen, and acids, as well as a good protector against short exposure to high temperatures and pressure [111].

Despite the numerous considerations, it has been found that artificial cells for bacterial cell therapy can be successfully stored and delivered in several different formulation modalities. Microencapsulated bacterial cells can be incorporated into foodstuffs such as fermented milk products (yogurt and ice cream) as active ingredients, or can be added as a nonactive supplement to food products in their microencapsulated form. Alternatively, microcapsules carrying bacterial cells can be dehydrated and incorporated into capsules or into pill form with a shelf-life of up to two years [112]. Institute Rosell partnered with Balchem have reported results in which encapsulated bacteria, incorporated into compressed tablets, have an unprecedented $100 \%$ delivery rate compared to the industry standard of $50 \%-75 \%$ bacterial survival in compressed tablets [111]. Also, microcapsules can be stored for months at low temperature in minimal solution and can be administered in drink format (Figure 5). Table 2 is a comprehensive list of the potential therapies

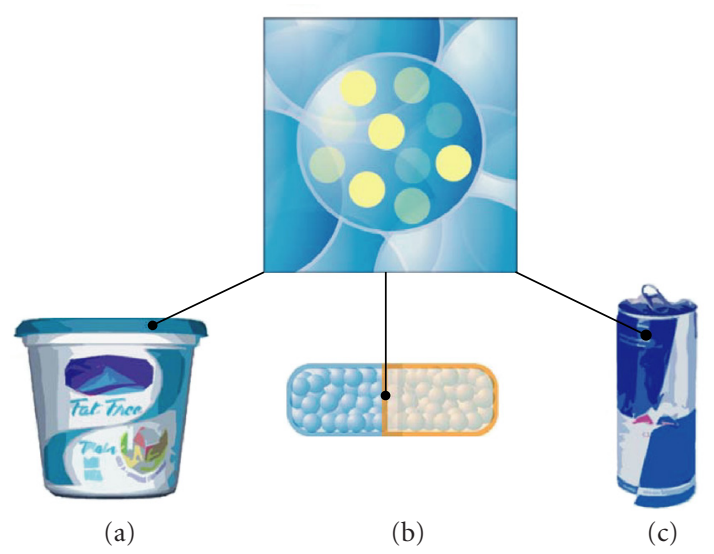

Figure 5. Artificial cells for bacterial cell therapy can be stored and delivered in several ways. (a) Microencapsulated bacterial cells can be incorporated into foodstuffs such as fermented milk products (yogurt and ice cream). (b) Microcapsules can be dehydrated and incorporated into capsules or into pill form with a shelf-life of up to two years. (c) Microcapsules can be stored for months at low temperature in minimal solution and can be administered in drink format.

based on the oral delivery of artificial cell microencapsulated bacterial cells for therapy $[63,75,88,96,97,98,99$, $100,101,102,103,104]$.

\section{FUTURE DIRECTION}

Recombinant technology will continue to generate valuable nonpathogenic genetically engineered bacterial cells and other genetically engineered cells that have potentially therapeutic functions or that produce therapeutic products useful in the treatment of disease. Future research must focus on overcoming the inherent obstacles in delivering these engineered products to therapeutically relevant and favorable sites. Thus, improvements must be centered on the design of microcapsule membranes, methods for improved cell harvest and microcapsule mass production, and methods of low-cost and effective storage. Currently, however, microencapsulation appears to be the best available technology to preserve the potency of probiotic products to be delivered into the GI tract; thus, future investigation may prove to allow for the efficient and effective use of bacteria in therapeutics or advanced food systems and allow manufactures to place assurances on the viability and quantity of bacteria in such advanced therapeutics and food products.

\section{ACKNOWLEDGMENT}

This work was supported by research grants from the Canadian Institute of Health Research (CIHR), Natural Sciences and Engineering Research Council (NSERC) of Canada, and Dairy Farmers of Canada (DFC). 
TABle 2. Potential therapies based on the oral delivery of microencapsulated bacterial cells.

\begin{tabular}{|c|c|c|c|}
\hline Disease/therapy & Culture & Mode of Action & References \\
\hline Kidney dialysis & E coli DH5 & $\begin{array}{l}\text { Inserted Klebsiella aerogenes urease gene causes overexpression of } \\
\text { the urease enzyme and the subsequent lowering of elevated blood } \\
\text { levels of urea. Blood levels of other metabolites, such as ammonia, } \\
\text { experience similar decreases showing that the DH5 cells normalize } \\
\text { elevated levels of several elevated metabolites during renal failure. }\end{array}$ & $\begin{array}{l}{[63,98]} \\
\text { US } \\
\text { Patent } \\
6217859\end{array}$ \\
\hline
\end{tabular}

Oxalate-degrading enzymes produced by Oxalobacter formigenes breaks down unwanted oxalate, a major risk factor for renal stone $\quad[99,100]$

Kidney stones O formigenes formation and growth in patients with idiopathic calcium-oxalate urolithiasis, and can be used to prevent subsequent evolution of Patent US kidney stones.

6242230

\begin{tabular}{ll}
\hline & \\
$\begin{array}{l}\text { Elevated blood } \\
\text { levels of } \\
\text { cholesterol }\end{array}$ & $\begin{array}{l}\text { LP80 }(\mathrm{pCBH} 1) \\
\text { and } L \text { reuteri }\end{array}$
\end{tabular}

Overproduced BSH enzyme deconjugates intraluminal bile acids making them less likely to be reabsorbed into the $\mathrm{ECH}$, causing de US [101] novo synthesis of bile acids in the liver from blood serum cholesterol. Provisional $L$ reuteri can be microencapsulated in combination with LP80 Patent (pCBH1), as it has been shown to precipitate and bind bile acids, 1770making them less bioavailable which may be important to their $325 \mathrm{USPR}$ carcinogenic potential.

FC/jm

The BSH enzyme is overproduced by LP80 (pCBH1) cells and hydrolyzes available conjugated bile acids in the intestinal lumen. $L$ reuteri, shown to precipitate and bind bile acids, then binds the deconjugated bile acids making them incapable of leaving the microcapsule and thus less bioavailable for exfoliation of the GI and any potential carcinogenic damage.
[101]

US

Provisional

Patent

$1770-$

325USPR

$\mathrm{FC} / \mathrm{jm}$
[101]

US

Provisional

Patent

$1770-$

325USPR

$\mathrm{FC} / \mathrm{jm}$ conjugated bile acids within microcapsules, mitigating the problems associated with excessive electrolyte and water secretion associated clinically with diarrhea and dehydration.

$[75,88$,

96, 97,

102]

Live microorganisms used as dietary supplements with the aim of

Probiotics

Lactobacillus Bifidobacterium benefiting the health of the consumer by positively influencing their intestinal microbial balance. Microencapsulated probiotic bacteria should help alleviate diarrhea, lower cholesterol, modulate immunity, and prevent colon cancer.

$[98,103]$

US

Lowers elevated blood levels of various amino acids through their metabolism, for example, phenylalanine in phenylketonuria.
Patents

6217859 ,

5147641 levels of

amino acids
Chang et al-cell convert, metabolize, or remove specific amino acids"
Live microorganisms delivered orally to a diver's large intestine during hyperbaric exposure to a gas mixture containing $\mathrm{H}_{2}$ or $\mathrm{N}_{2}$ metabolizes the $\mathrm{H}_{2}$ or $\mathrm{N}_{2}$ gas to other compounds such as methane or water for hydrogen and ammonia for nitrogen to prevent decompression sickness or reduce decompression time.
[104]

US Patent

5922317 nitrogen and $\quad \mathrm{N}_{2}$ fixing

hydrogen gas (Enterobacteriaceae) 


\section{REFERENCES}

[1] Stacia M. Foundetions and frontiers. In: Deborah, ed. Human Physiology; 1990:526-527.

[2] Wrong OM, Chadwick VS, Edmonds CJE. The Large Intestine. Lancaster, UK: MTS Press; 1981

[3] Metchnikoff E. The Prolongation of Life. London, UK: Heinemann Publishers; 1907.

[4] Saavedra JM, Bauman NA, Oung I, Perman JA, Yolken RH. Feeding of Bifidobacterium bifidum and Streptococcus thermophilus to infants in hospital for prevention of diarrhoea and shedding of rotavirus. Lancet. 1994;344(8929):1046-1049.

[5] Oberhelman RA, Gilman RH, Sheen P, et al. A placebo-controlled trial of Lactobacillus $G G$ to prevent diarrhea in undernourished Peruvian children. J Pediatr. 1999;134(1):15-20.

[6] Saavedra JM. Microbes to fight microbes: a not so novel approach to controlling diarrheal disease. $J$ Pediatr Gastroenterol Nutr. 1995;21(2):125-129.

[7] Matsuzaki T, Chin J. Modulating immune responses with probiotic bacteria. Immunol Cell Biol. 2000;78(1):67-73.

[8] Phuapradit P, Varavithya W, Vathanophas K, et al. Reduction of rotavirus infection in children receiving bifidobacteria-supplemented formula. J Med Assoc Thai. 1999;82(suppl 1):S43-S48.

[9] Singh J, Rivenson A, Tomita M, Shimamura S, Ishibashi N, Reddy BS. Bifidobacterium longum, a lactic acid-producing intestinal bacterium inhibits colon cancer and modulates the intermediate biomarkers of colon carcinogenesis. Carcinogenesis. 1997;18(4):833-841.

[10] Akiyama K, et al. Effects of oral administration of Bifidobacterium breve on development of intestinal microflora in extremely premature infants. Acta Neonatologica Japonica. 1994;30:130-137.

[11] McIntosh GH, Royle PJ, Playne MJ. A probiotic strain of $L$ acidophilus reduces DMH-induced large intestinal tumors in male Sprague-Dawley rats. Nutr Cancer. 1999;35(2):153-159.

[12] Anderson JW, Gilliland SE. Effect of fermented milk (yogurt) containing Lactobacillus acidophilus L1 on serum cholesterol in hypercholesterolemic humans. J Am Coll Nutr. 1999;18(1):43-50.

[13] Schaafsma G, Meuling WJ, van Dokkum W, Bouley C. Effects of a milk product, fermented by Lactobacillus acidophilus and with fructooligosaccharides added, on blood lipids in male volunteers. Eur J Clin Nutr. 1998;52(6):436-440.

[14] Lodinova-Zadnikova R, Sonnenborn U. Effect of preventive administration of a nonpathogenic Escherichia coli strain on the colonization of the intestine with microbial pathogens in newborn infants. Biol Neonate. 1997;71(4):224-232.

[15] Simenhoff ML, Dunn SR, Zollner GP, et al. Biomodulation of the toxic and nutritional effects of small bowel bacterial overgrowth in end-stage kidney disease using freeze-dried Lactobacillus acidophilus. Miner Electrolyte Metab. 1996;22(1-3):9296.

[16] Campieri C, Campieri M, Bertuzzi V, et al. Reduction of oxaluria after an oral course of lactic acid bacteria at high concentration. Kidney Int. 2001;60(3):1097-1105.

[17] Borody TJ, inventor. Treatment of gastrointestinal disorders with a fecal composition or a composition of bacteroides and E coli. US Patent 5443826. 1995.

[18] Arunachalam K, Gill HS, Chandra RK. Enhancement of natural immune function by dietary consumption of Bifidobacterium lactis (HN019). Eur J Clin Nutr. 2000;54(3):263-267.

[19] Kaila M, Isolauri E, Soppi E, Virtanen E, Laine S, Arvilommi H. Enhancement of the circulating antibody secreting cell response in human diarrhea by a human Lactobacillus strain. Pediatr Res. 1992;32(2):141-144.

[20] Majamaa H, Isolauri E, Saxelin M, Vesikari T. Lactic acid bacteria in the treatment of acute rotavirus gastroenteritis. J Pediatr Gastroenterol Nutr. 1995;20(3):333-338.

[21] Steidler L, Hans W, Schotte L, et al. Treatment of murine colitis by Lactococcus lactis secreting interleukin-10. Science. 2000;289(5483):13521355.

[22] Rao AV, Shiwnarain N, Maharaj I. Survival of microencapsulated Bifidobacterium pseudolongum in simulated gastric and intestinal juices. Can Inst Food Sci Technol J. 1989;22:345-349.

[23] Woo CJ, Lee KY, Heo TR. Improvement of Bifidobacterium longum stability using cell-entrapment technique. Journal of Microbiology and Biotechnology. 1999:132-139.

[24] Sun W, Griffiths MW. Survival of bifidobacteria in yogurt and simulated gastric juice following immobilization in gellan-xanthan beads. Int J Food Microbiol. 2000;61(1):17-25.

[25] Saavedra JM, Tschernia A. Human studies with probiotics and prebiotics: clinical implications. $\mathrm{Br}$ J Nutr. 2002;87 (suppl 2):S241-S246.

[26] Chin J, Turner B, Barchia I, Mullbacher A. Immune response to orally consumed antigens and probiotic bacteria. Immunol Cell Biol. 2000;78(1):55-66.

[27] Vardjan N, Kopitar AN, Ihan Hren N, Malovrh T, Wraber B, Ihan A. Immune response in lymphocyte cultures stimulated by oral bacteria preparations. Pflugers Arch. 2000;440(suppl 5):R67-R69.

[28] Vitini E, Alvarez S, Medina M, Medici M, de Budeguer MV, Perdigon G. Gut mucosal immunostimulation by lactic acid bacteria. Biocell. 2000;24(3):223-232.

[29] Lu L, Walker WA. Pathologic and physiologic interactions of bacteria with the gastrointestinal epithelium. Am J Clin Nutr. 2001;73(6):1124S-1130S.

[30] De Smet I, Van Hoorde L, De Saeyer M, Vande 
Woestyne $\mathrm{M}$, Verstraete $\mathrm{W}$. In vitro study of bile salt hydrolase (BSH) activity of BSH isogenic Lactobacillus plantarum 80 strains and estimation of cholesterol lowering through enhanced BSH activity. Microbial Ecology in Health and Disease. 1994;7:315-329.

[31] Oggioni MR, Manganelli R, Contorni M, Tommasino $\mathrm{M}$, Pozzi G. Immunization of mice by oral colonization with live recombinant commensal streptococci. Vaccine. 1995;13(8):775-779.

[32] Wadolkowski EA, Laux DC, Cohen PS. Colonization of the streptomycin-treated mouse large intestine by a human fecal Escherichia coli strain: role of adhesion to mucosal receptors. Infect Immun. 1988;56(5):1036-1043.

[33] Sheen P, Oberhelman RA, Gilman RH, Cabrera L, Verastegui M, Madico G. Short report: a placebocontrolled study of Lactobacillus GG colonization in one-to-three-year-old Peruvian children. Am J Trop Med Hyg. 1995;52(5):389-392.

[34] Kirjavainen PV, Tuomola EM, Crittenden RG, et al. In vitro adhesion and platelet aggregation properties of bacteremia-associated Lactobacilli. Infect Immun. 1999;67(5):2653-2655.

[35] Salminen S, von Wright A, Morelli L, et al. Demonstration of safety of probiotics-a review. Int J Food Microbiol. 1998;44(1-2):93-106.

[36] Reuter G. Probiotics-possibilities and limitations of their application in food, animal feed, and in pharmaceutical preparations for men and animals [in German]. Berl Munch Tierarztl Wochenschr. 2001;114(11-12):410-419.

[37] Donohue DC, Salminen S. Safety assessment of probiotic bacteria. Asia Pac J Clin Nutr. 1996;5:2528.

[38] Hilton E, Kolakowski P, Singer C, Smith M. Efficacy of Lactobacillus $G G$ as a diarrheal preventive in travelers. J Travel Med. 1997;4(1):41-43.

[39] Raza S, Graham SM, Allen SJ, Sultana S, Cuevas L, Hart CA. Lactobacillus GG promotes recovery from acute nonbloody diarrhea in Pakistan. Pediatr Infect Dis J. 1995;14(2):107-111.

[40] Raza S, Graham SM, Allen SJ, et al. Lactobacillus $G G$ in acute diarrhea. Indian Pediatr. 1995;32(10):1140-1142.

[41] Shornikova AV, Casas IA, Mykkanen H, Salo E, Vesikari T. Bacteriotherapy with Lactobacillus reuteri in rotavirus gastroenteritis. Pediatr Infect Dis J. 1997;16(12):1103-1107.

[42] Shornikova AV, Isolauri E, Burkanova L, Lukovnikova S, Vesikari T. A trial in the Karelian Republic of oral rehydration and Lactobacillus $G G$ for treatment of acute diarrhoea. Acta Paediatr. 1997;86(5):460-465.

[43] Siitonen S, Vapaatalo H, Salminen S, et al. Effect of Lactobacillus GG yoghurt in prevention of antibiotic associated diarrhoea. Ann Med. 1990;22(1):5759.
[44] Arvola T, Laiho K, Torkkeli S, et al. Prophylactic Lactobacillus $G G$ reduces antibiotic-associated diarrhea in children with respiratory infections: a randomized study. Pediatrics. 1999;104(5):e64.

[45] Bellomo G, Mangiagli A, Nicastro L, Frigerio G. A controlled double-blind study of SF68 strain as a new biological preparation for the treatment of diarrhoea in pediatrics. Curr Ther Res. 1980;28:927936.

[46] Isolauri E, Juntunen M, Rautanen T, Sillanaukee P, Koivula T. A human Lactobacillus strain (Lactobacillus casei sp strain GG) promotes recovery from acute diarrhea in children. Pediatrics. 1991;88(1):90-97.

[47] Hirayama K, Rafter J. The role of lactic acid bacteria in colon cancer prevention: mechanistic considerations. Antonie Van Leeuwenhoek. 1999;76(14):391-394.

[48] Malin M, Isolauri E, Pikkarainen P, Karikoski R, Isolauri J. Enhanced absorption of macromolecules. A secondary factor in Crohn's disease. Dig Dis Sci. 1996;41(7):1423-1428.

[49] Michetti P, Dorta G, Wiesel PH, et al. Effect of whey-based culture supernatant of Lactobacillus acidophilus (johnsonii) La1 on Helicobacter pylori infection in humans. Digestion. 1999;60(3):203209.

[50] Layer P, Keller J. Lipase supplementation therapy: standards, alternatives, and perspectives. Pancreas. 2003;26(1):1-7.

[51] Raimondo M, DiMagno EP. Lipolytic activity of bacterial lipase survives better than that of porcine lipase in human gastric and duodenal content. Gastroenterology. 1994;107(1):231-235.

[52] Pelto L, Isolauri E, Lilius EM, Nuutila J, Salminen S. Probiotic bacteria down-regulate the milk-induced inflammatory response in milkhypersensitive subjects but have an immunostimulatory effect in healthy subjects. Clin Exp Allergy. 1998;28(12):1474-1479.

[53] Link-Amster H, Rochat F, Saudan KY, Mignot O, Aeschlimann JM. Modulation of a specific humoral immune response and changes in intestinal flora mediated through fermented milk intake. FEMS Immunol Med Microbiol. 1994;10(1):55-63.

[54] Schiffrin EJ, Rochat F, Link-Amster H, Aeschlimann JM, Donnet-Hughes A. Immunomodulation of human blood cells following the ingestion of lactic acid bacteria. J Dairy Sci. 1995;78(3):491-497.

[55] Taranto MP, Medici M, Perdigon G, Ruiz Holgado AP, Valdez GF. Effect of Lactobacillus reuteri on the prevention of hypercholesterolemia in mice. J Dairy Sci. 2000;83(3):401-403.

[56] Hida M, Aiba Y, Sawamura S, Suzuki N, Satoh T, Koga Y. Inhibition of the accumulation of uremic toxins in the blood and their precursors in the feces after oral administration of Lebenin, a lactic acid bacteria preparation, to uremic patients 
undergoing hemodialysis. Nephron. 1996;74(2): 349-355.

[57] Hokama S, Honma Y, Toma C, Ogawa Y. Oxalatedegrading Enterococcus faecalis. Microbiol Immunol. 2000;44(4):235-240.

[58] Chang TM, Prakash S. Artificial cells for bioencapsulation of cells and genetically engineered E coli for cell therapy, gene therapy, and removal of urea and ammonia. Methods Mol Biol. 1997;63:343-358.

[59] Chang TMS. Semipermeable microcapsules. Science. 1964;146:524-525.

[60] Lim F, Sun AM. Microencapsulated islets as bioartificial endocrine pancreas. Science. 1980;210(4472): 908-910.

[61] Chang PL. Encapsulation for somatic gene therapy. Ann N Y Acad Sci. 1999;875:146-158.

[62] Sefton MV, May MH, Lahooti S, Babensee JE. Making microencapsulation work: conformal coating, immobilization gels and in vivo performance. $J$ Control Release. 2000;65(1-2):173-186.

[63] Prakash S, Chang TM. Microencapsulated genetically engineered live E coli DH5 cells administered orally to maintain normal plasma urea level in uremic rats. Nat Med. 1996;2(8):883-887.

[64] Prakash S, Chang TM. In vitro and in vivo uric acid lowering by artificial cells containing microencapsulated genetically engineered $E$ coli $\mathrm{DH} 5$ cells. Int J Artif Organs. 2000;23(7):429-435.

[65] Prakash S, Chang TM. Growth kinetics of genetically engineered $E$ coli $\mathrm{DH} 5$ cells in artificial cell APA membrane microcapsules: preliminary report. Artif Cells Blood Substit Immobil Biotechnol. 1999;27(3):291-301.

[66] Prakash S, Chang TM. Microencapsulated genetically engineered $E$ coli DH5 cells for plasma urea and ammonia removal based on: 1. column bioreactor and 2. oral administration in uremic rats. Artif Cells Blood Substit Immobil Biotechnol. 1996;24(3):201-218.

[67] Prakash S, Chang TM. Artificial cell microcapsules containing genetically engineered E coli DH5 cells for in-vitro lowering of plasma potassium, phosphate, magnesium, sodium, chloride, uric acid, cholesterol, and creatinine: a preliminary report. Artif Cells Blood Substit Immobil Biotechnol. 1999;27(5-6):475-481.

[68] Chang TM. Future prospects for artificial blood. Trends Biotechnol. 1999;17(2):61-67.

[69] Ross CJ, Ralph M, Chang PL. Delivery of recombinant gene products to the central nervous system with nonautologous cells in alginate microcapsules. Hum Gene Ther. 1999;10(1):49-59.

[70] Uludag H, De Vos P, Tresco PA. Technology of mammalian cell encapsulation. Adv Drug Deliv Rev. 2000;42(1-2):29-64.

[71] Prakash S, Jones ML. Engineering artificial cells for cell therapy. In: 2nd World Engineering Congress. Sarawak, Malaysia; 2002.
[72] Chang TM, Prakash S. Therapeutic uses of microencapsulated genetically engineered cells. $\mathrm{Mol}$ Med Today. 1998;4(5):221-227.

[73] Chang TMS, Wong H, inventors. Method for encapsulating biologically active material including cells. US Patent 5084 350. February 16, 1990.

[74] Wong H, Chang TM. A novel two step procedure for immobilizing living cells in microcapsules for improving xenograft survival. Biomater Artif Cells Immobilization Biotechnol. 1991;19(4):687-697.

[75] Favaro-Trindade CS, Grosso CR. Microencapsulation of $L$ acidophilus (La-05) and $B$ lactis (Bb12) and evaluation of their survival at the $\mathrm{pH}$ values of the stomach and in bile. J Microencapsul. 2002;19(4):485-494.

[76] Modler HW, Villa-Garcia L. The growth of Bifidobacterium longum in a whey-based medium and viability of this organism in frozen yoghurt with low and high levels of developed acidity. Cult Dairy Prod. 1993;28:4-8.

[77] Audet P, Paguin C, Lacroix C. Effect of medium and temperature of storage on viability of lacticacid bacteria immobilized in kappa-carrageenanlocust bean gum gel beads. Biotechnology Techniques. 1991;5:307-312.

[78] Truelstrup Hansen L, Allan-Wojtas PM, Jin YL, Paulson AT. Survival of Ca-alginate microencapsulated Bifidobacterium spp. in milk and simulated gastrointestinal conditions. Food Microbiology. 2002;19(1):35-45.

[79] Eikmeier H, Westmeier F, Rehm HJ. Morphological development of Aspergillus niger immobilized in Ca-alginate and kappa-carrageenan. Appl Microbiol Biotechnol. 1984;19:53-57.

[80] Baichwal AR, Staniforth JN, inventors. Agglomerated hydrophilic complexes with multi-phasic release characteristics. US Patent 5670 168. 1997.

[81] Audet P, Paquin C, Lacroix C. Immobilized growing lactic acid bacteria with $\mathrm{K}$-carrageenanlocust bean gum gel. Appl Microbiol Biotechnol. 1988;29:11-18.

[82] Audet P, Paquin C, Lacroix C. Batch fermentations with a mixed culture of lactic acid bacteria immobilized seperately in k-carrageenan locust bean gum gel beads. Appl Microbiol Biotechnol. 1990;32:662668.

[83] Weisz, RR. Hypokalemia-induced clinical neurophysiological changes in the human neuromuscular-junction. Clinical Research. 1980;28: A752.

[84] Norton S, Lacroix C, Vuillemard JC. Effect of pH on the morphology of Lactobacillus helveticus in free cell batch and immobilized-cell continuous fermentation. Food Biotechnol. 1993;7:235-251.

[85] Sanderson GR. Gellan gum. In: Food Gels. New York: Elsevier; 1990:201-233.

[86] Esquisabel A, Hernandez RM, Igartua M, Gascon AR, Calvo B, Pedraz JL. Preparation and stability of 
agarose microcapsules containing BCG. J Microencapsul. 2002;19(2):237-244.

[87] Losgen H, Brunner G, Holloway CJ, et al. Large agarose beads for extracorporeal detoxification systems. Biomater Med Devices Artif Organs. 1978;6(2):151-173.

[88] Kailasapathy K. Microencapsulation of probiotic bacteria: technology and potential applications. Curr Issues Intest Microbiol. 2002;3(2):39-48.

[89] Lian WC, Hsiao HC, Chou CC. Survival of bifidobacteria after spray-drying. Int J Food Microbiol. 2002;74(1-2):79-86.

[90] Narayani R, Rao KP. Gelatin microsphere cocktails of different sizes for the controlled release of anticancer drugs. Int J Pharm. 1996;143:255-258.

[91] Lutze V, Winzer A. Radiochemical studies of the influence of photographically active substances on the kinetics of the mass-transfer at silverhalide crystals .9. activation parameters for the mass-transfer in the course of the OstwaldRipening. Journal of Information Recording Materials. 1994;22(1):65-77.

[92] Crittenden R, Laitila A, Forssell P, et al. Adhesion of bifidobacteria to granular starch and its implications in probiotic technologies. Appl Environ Microbiol. 2001;67(8):3469-3475.

[93] Carr ME, Doane WM, Wing RE, Bagley EB, inventors. Starch encapsulation of biologically active agents by a continuous process. US Patent 5183 690. June 25, 1990.

[94] Rosenberg M, inventors. Milk derived whey protein-based microencapsulating agents and a method of use. US Patent 5601760.1994.

[95] Shasha BS, Dunkle RL. Starch encapsulation of entomopathogens. US Patent 4859 377. 1987.

[96] O’Riordan K, Andrews D, Buckle K, Conway P. Evaluation of microencapsulation of a Bifidobacterium strain with starch as an approach to prolonging viability during storage. J Appl Microbiol. 2001;91(6):1059-1066.

[97] Sultana K, Godward G, Reynolds N, Arumugaswamy R, Peiris P, Kailasapathy K. Encapsulation of probiotic bacteria with alginate-starch and evaluation of survival in simulated gastrointestinal conditions and in yoghurt. Int J Food Microbiol. 2000;62(1-2):47-55.

[98] Chang TMS, Prakash S, inventors. Microencapsulated genetically engineered microorganisms for clinical application. US Patent 6217 859. July 3, 1997.

[99] Batich C, Vaghefi F, inventors. Process for microencapsulating cells. US Patent 6242 230. November 8, 1999.

[100] Duncan SH, Richardson AJ, Kaul P, Holmes RP, Allison MJ, Stewart CS. Oxalobacter formigenes and its potential role in human health. Appl Environ Microbiol. 2002;68(8):3841-3847.

[101] Jones ML, Chen H, Ouyang W, Metz T, Prakash
S. Deconjugation of bile acids with immobilized genetically engineered Lactobacillus plantarum 80 (pCBH1). Applied Bionics and Biomechanics. In press.

[102] Saarela M, Mogensen G, Fonden R, Matto J, Mattila-Sandholm T. Probiotic bacteria: safety, functional and technological properties. J Biotechnol. 2000;84(3):197-215.

[103] Chang TMS, Bourget L, Lister C, inventors. Microcapsule for the removal of specific amino acids through the entero-portal recirculation. US Patent 5147 641. June 24, 1991.

[104] Kayar SR, Axley MJ, inventors. Accelerated gas removal from divers' tissues utilizing gas metabolizing bacteria. US Patent 5922 317. May 6, 1997.

[105] Kulseng B, Skjak-Braek G, Ryan L, et al. Transplantation of alginate microcapsules: generation of antibodies against alginates and encapsulated porcine islet-like cell clusters. Transplantation. 1999;67(7):978-984.

[106] Prakash S, Chang TMS. Preparation and in vitro analysis of microencapsulated genetically engineered $E$ coli DH5 cells for urea and ammonia removal. Biotechnology and Bioengineering. 1995;46 (6):621-626.

[107] Awrey DE, Tse M, Hortelano G, Chang PL. Permeability of alginate microcapsules to secretory recombinant gene products. Biotechnology and Bioengineering. 1996;52(4):472-484.

[108] Schneider S, Feilen PJ, Slotty V, et al. Multilayer capsules: a promising microencapsulation system for transplantation of pancreatic islets. Biomaterials. 2001;22(14):1961-1970.

[109] Chen H, Ouyang W, Jones ML, Metz T, Prakash S. Preparation of new multi-layer alginate-chitosan based microcapsules for biomedical applications. In: Polymers in Medicine and Biology: 2002. Rohnert Park, Calif American Chemical Society; 2002.

[110] Ouyang W, Chen H, Jones ML, Metz T, Prakash S. Novel artificial cell formulation: design, preparation and morphology studies. In: Polymers in Medicine and Biology: 2002. Rohnert Park, Calif American Chemical Society ; 2002.

[111] Siuta-Cruce P, Goulet J. Improving probiotic survival rates. Food Technology. 2001;55(10):36-42.

[112] Institut Rosell-Lallemand Newsletter Number 2. Montreal, QC, Canada: Institut Rosell-Lallemand; 2002. Report.

* Corresponding author.

E-mail: satya.prakash@mcgill.ca

Fax: +1 514398 7461; Tel: +1 5143983676 

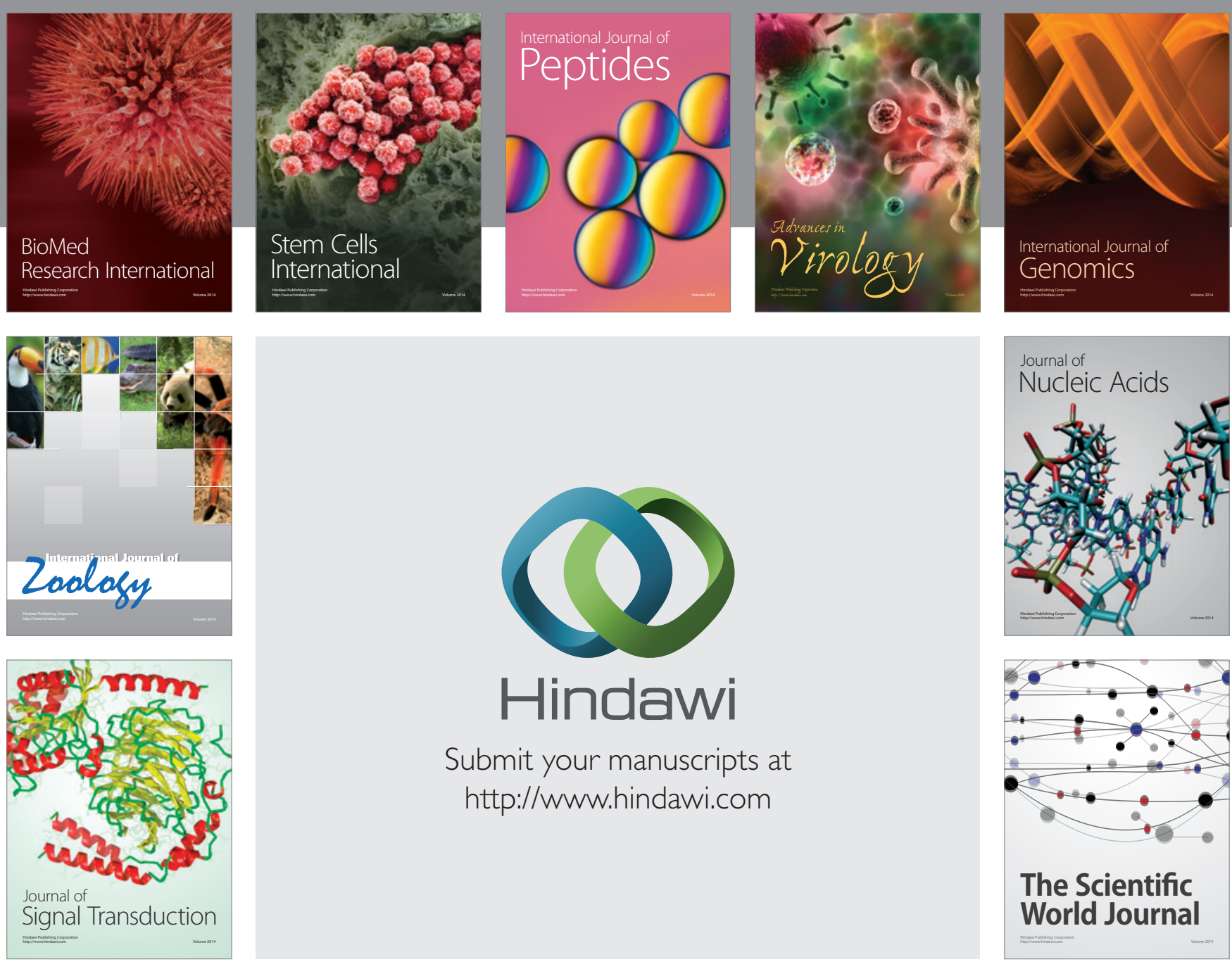

Submit your manuscripts at

http://www.hindawi.com
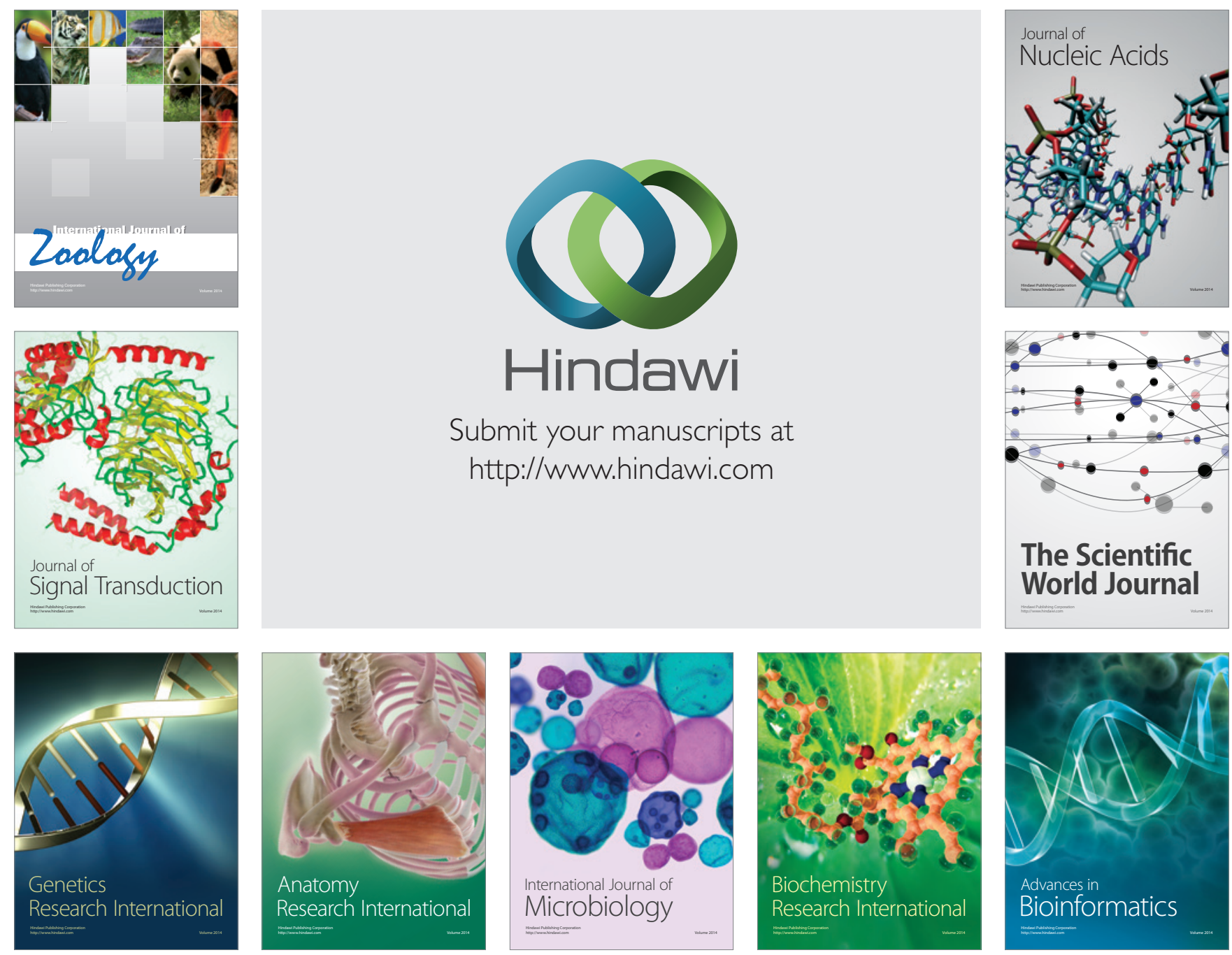

The Scientific World Journal
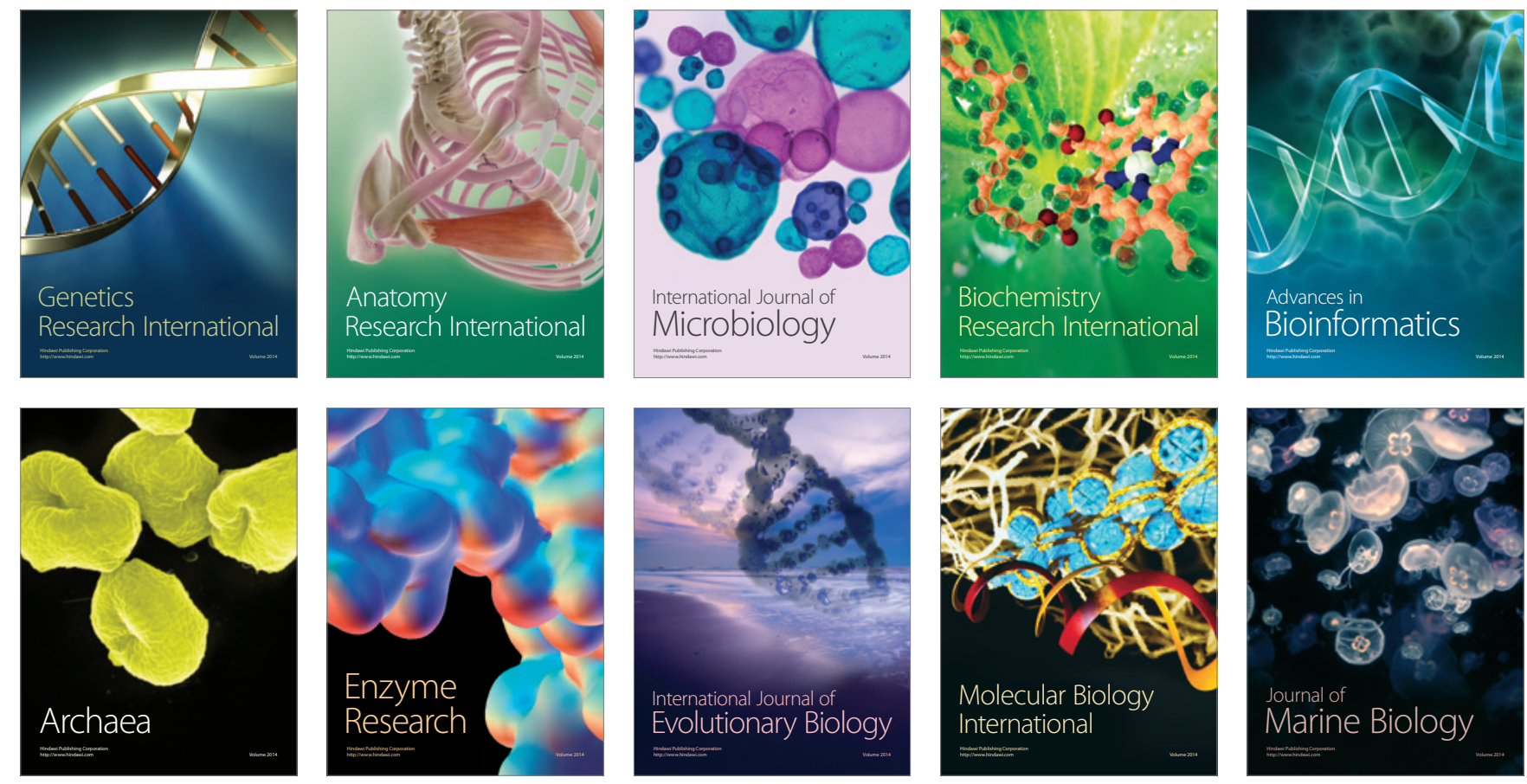